\title{
Study of the amino acid composition of thermoacid coagulation fractions of probiotic products
}

\author{
Natalia Rodionova, Evgeny Popov *, Ekaterina Pozhidaeva, Natalia Zakharova \\ and Michael Syromyatnikov \\ Voronezh State University of Engineering Technologies, Voronezh, Russian Federation
}

\begin{abstract}
The developed mathematical model allows good prediction of the quantity of heat saved based on applied technological parameters. The process of distribution of amino acids between whey and protein clot was studied during thermoacid coagulation of milk fermented by a consortium of bifidobacteria Lactococcus lactis subsp. diacetilactis, Streptococcus thermophiles, Propionibacterium freudenreichii, Bifidobacterium bifidum with an active cell concentration of $10^{9} \mathrm{CFU} / \mathrm{ml}$. The distribution of amino acids indicates the predominant transition of amino acids of microbial origin into coagulum. An increase in the content of such amino acids as lysine and leucine was found, the concentration of valine, isoleucine, methionine, threonine, phenlalanine, which had a rate of more than $100 \%$, decreased. The predominant transfer of microbial exopolysaccharides metabolic products of probiotic microorganisms - is noted in serum, which makes it an especially valuable biological resource for the production of eubiotic drinks.
\end{abstract}

\section{Introduction}

The effects of probiotic products have been proven by numerous studies in the field of medicine, physiology, microbiology, however, due to the extreme variety of types of microorganisms that inhabit the human body and the functions they perform, the process of obtaining new knowledge in this direction continues. Human normal flora is considered today as an integral part of the body, its unique extracorporeal organ, which exclusively provides a number of important functions, due to the variety of cellular metabolism of bacteria of normal microflora, enzymes, vitamins, hormones, and other biologically active compounds of microbial origin are involved in the morphogenesis and functions of various host systems [1-5].

The results of experimental studies indicate that the products of metabolism or decay of microflora, for example, due to enzymatic or thermal effects, have more pronounced biocorrecting and bioremediating properties compared to microbial cells in an active form. In this regard, obtaining fractions of separation of fermented systems by thermal coagulation with obtaining protein coagulum and whey will allow obtaining new curd and whey

\footnotetext{
*Corresponding author: e_s_popov@mail.ru
} 
products containing microflora metabolites and thermally inactivated forms of probiotic microorganisms [6-8].

\section{Material and methods}

The object of experimental research was the biomass of probiotic microorganisms containing Lactococcus lactis subsp. diacetilactis, Streptococcus thermophiles, Propionibacterium freudenreichii, Bifidobacterium bifidum with an active cell concentration of $10^{9} \mathrm{CFU} / \mathrm{ml}[9,10]$.

At this stage of the study, the process of distribution of amino acids between whey and protein clot was studied during thermoacid coagulation of milk fermented by a consortium of bifidobacteria Lactococcus lactis subsp. diacetilactis, Streptococcus thermophiles, Propionibacterium freudenreichii, Bifidobacterium bifidum. The fermented curd was heated to a temperature of $50-55{ }^{\circ} \mathrm{C}$, kept for $40-50 \mathrm{~min}$ at this temperature, and the whey was separated by filtration through a lavsan filter [11].

\section{Results and discussion}

The concentration of bifidobacteria in the obtained protein clot and in the serum was $10^{7}-10^{8} \mathrm{CFU} / \mathrm{g}$. The content of essential amino acids in test samples of coagulum and serum is shown in Fig. 1-2.

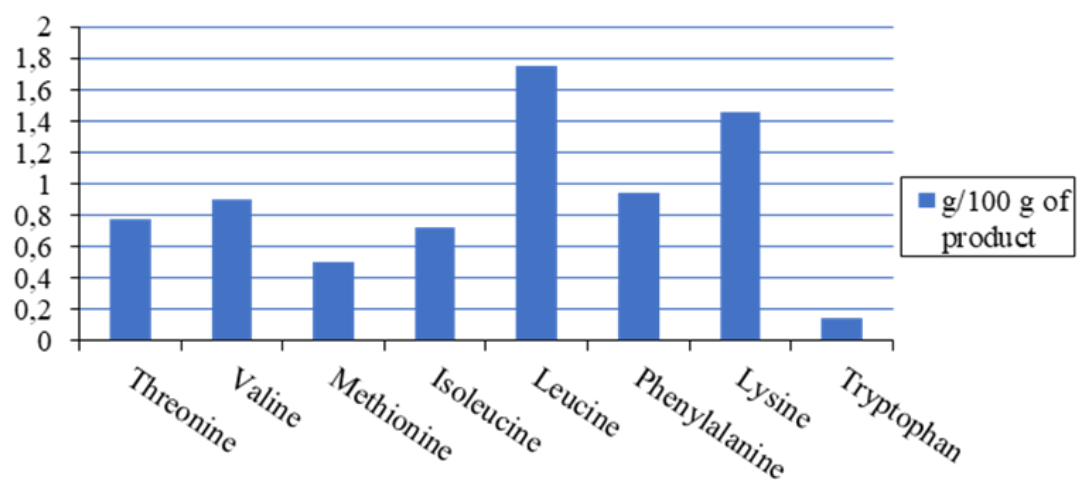

Fig. 1. The content of irreplaceable amino acids in the coagulum during fermentation by the consortium Lactococcus lactis subsp. diacetilactis, Streptococcus thermophiles, Propionibacterium freudenreichii, Bifidobacterium bifidum. 


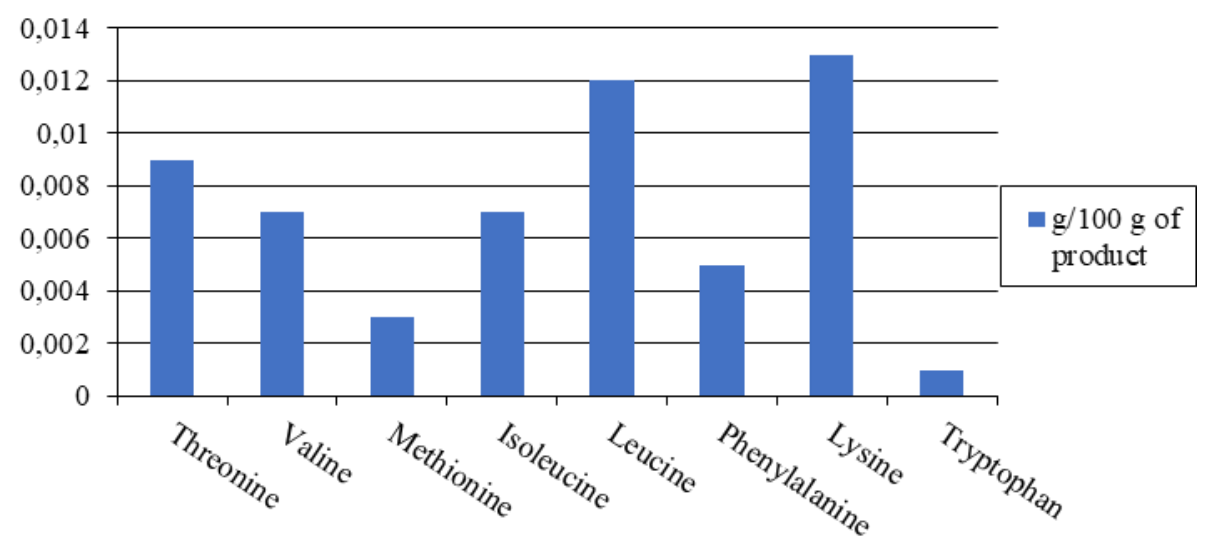

Fig. 2. The content of essential amino acids in serum during fermentation of Lactococcus lactis subsp. diacetilactis, Streptococcus thermophiles, Propionibacterium freudenreichii, Bifidobacterium bifidum.

The regularity of the distribution of amino acids, including those of bacterial origin, between the fractions of thermoacid coagulation with serum (Table 1) and coagulum (Table 2) was investigated.

Table 1. The degree of transition of amino acids into serum during thermoacid coagulation of fermented probiotic systems.

\begin{tabular}{|l|c|c|c|c|}
\hline \multirow{2}{*}{\begin{tabular}{c}
\multirow{2}{*}{$\begin{array}{c}\text { Essential } \\
\text { amino acids }\end{array}$} \\
\cline { 2 - 4 }
\end{tabular}} & \multicolumn{3}{|c|}{ Content in 100 g of product } & $\begin{array}{c}\text { Conversion } \\
\text { rate, \% }\end{array}$ \\
\hline Valine & 0.13 & Fermented milk & Serum & 4.1 \\
\hline Isoleucine & 0.11 & 0.17 & 0.007 & 5.0 \\
\hline Leucine & 0.26 & 0.14 & 0.007 & 3.5 \\
\hline Lysine & 0.22 & 0.34 & 0.012 & 4.6 \\
\hline Methionine & 0.07 & 0.28 & 0.013 & 3.0 \\
\hline Threonine & 0.12 & 0.1 & 0.003 & 6.0 \\
\hline Tryptophan & 0.02 & 0.15 & 0.009 & 2.5 \\
\hline Phenylalanine & 0.13 & 0.04 & 0.001 & 2.9 \\
\hline
\end{tabular}

Table 2. The degree of concentration of amino acids in the coagulum during thermoacid coagulation of milk fermented by the consortium Lactococcus lactis subsp. diacetilactis, Streptococcus thermophiles, Propionibacterium freudenreichii, Bifidobacterium bifidum.

\begin{tabular}{|l|c|c|c|c|}
\hline \multirow{2}{*}{$\begin{array}{c}\text { Essential } \\
\text { amino acids }\end{array}$} & \multicolumn{3}{|c|}{ Content in 100 g of product } & $\begin{array}{c}\text { Concentration } \\
\text { degree }\end{array}$ \\
\cline { 2 - 5 } & Raw milk & Fermented milk & Coagulum & 6.94 \\
\hline Valine & 0.13 & 0.17 & 0.90 & 6.54 \\
\hline Isoleucine & 0.11 & 0.14 & 0.72 & 6.72 \\
\hline Leucine & 0.26 & 0.34 & 1.75 & 6.60 \\
\hline Lysine & 0.22 & 0.28 & 1.45 & 7.16 \\
\hline Methionine & 0.07 & 0.10 & 0.50 & 6.50 \\
\hline Threonine & 0.12 & 0.15 & 0.78 & 7.35 \\
\hline Tryptophan & 0.02 & 0.04 & 0.15 & 7.23 \\
\hline Phenylalanine & 0.13 & 0.17 & 0.94 & \\
\hline
\end{tabular}

The amino acid rate of coagulum and serum from a clot fermented by a consortium of bifidobacteria was determined (Table 3 ). The data obtained make it possible to evaluate the 
biological value of fractions of thermoacid separation enriched with metabolites of bifidobacteria, as well as products with their use - drinks, curd pancakes, curd desserts.

Table 3. Amino acid rate of coagulum and whey during milk fermentation by the consortium Lactococcus lactis subsp. diacetilactis, Streptococcus thermophiles, Propionibacterium freudenreichii, Bifidobacterium bifidum.

\begin{tabular}{|l|c|c|c|c|}
\hline \multirow{2}{*}{\begin{tabular}{c}
\multirow{2}{*}{$\begin{array}{c}\text { Essential } \\
\text { amino acids }\end{array}$} \\
\cline { 2 - 5 }
\end{tabular}} & \multicolumn{2}{|c|}{ Experiment } & \multicolumn{2}{c|}{ Control } \\
\hline Valine & 97.6 & Serum & Cottage cheese & Serum \\
\hline Isoleucine & 97.25 & 46.00 & 134.17 & 137.5 \\
\hline Leucine & 134.86 & 57.50 & 154.13 & 125.7 \\
\hline Lysine & 142.91 & 77.14 & 127.94 & 145.4 \\
\hline $\begin{array}{l}\text { Methionine } \\
\text { cysteine }\end{array}$ & 97.14 & 285.71 & 64.58 & 131.4 \\
\hline Threonine & 105.50 & 75.00 & 144.22 & 100.0 \\
\hline $\begin{array}{l}\text { Phenylalanine } \\
\text { tyrosine }\end{array}$ & 121.50 & 28.33 & 175.29 & 130.0 \\
\hline
\end{tabular}

The data obtained indicate that when the initial mixture is fermented by a consortium of bifidobacteria for the production of probiotic drinks with a high protein content or curd products, a protein fraction can be obtained enriched with microbial metabolites of protein nature.

\section{Conclusions}

Thus, an increase in the content of such amino acids as lysine and leucine was found in the coagulum, the concentration of valine, isoleucine, methionine, threonine, phenlalanine, which had a rate of more than $100 \%$, decreased. The coefficient of excess of amino acids decreased to 0.14 and the coefficient of protein utilization increased to 0.71 ; however, the most valuable property of these products, probably, should be considered not the generally accepted characteristics of proteins, but the presence of microbial metabolites of protein nature [12].

The serum obtained as a result of thermal coagulation of the clot does not contain significant amounts of amino acids, the protein concentration was $0.3 \%$, which is significantly lower than traditional values, this may be due to the phenomenon of membraneless osmosis, which occurs due to the presence of significant amounts of polysaccharides of microbial origin in the coagulated environment. At the same time, it should be noted that the presence of these substances in serum in this case makes it an especially valuable biological resource for the production of eubiotic drinks.

This research was supported by the Russian Science Foundation (agreement No. 19-7610023).

\section{References}

1. N.S. Rodionova, E.S. Popov, M.Y. Syromyatnikov, E.A. Artemova, E.A. Pozhidaeva Proceedings of the 1st International Symposium Innovations in Life Sciences, 7, 262 (2019).

2. N.S. Rodionova, E.S. Popov, A.A. Khitrov, N.A. Rodionova, E.I. Egorova TCHE Quimica Journal, 17, 720 (2020) 
3. U. Roobab Current opinion in Food Science, 32, 17 (2020)

4. T. Teneva-Angelova, I. Hristova, A. Pavlov, D. Beshkova Advances in Biotechnology for Food Industry, 4, 91 (2018)

5. M. Zamroziewicz, M. Tanveer Talukdar, C. Zwilling, A. Barbey NeuroImage, 161, 241 (2017)

6. F. Zuo, S. Chen, H. Marcotte Biotechnology Advances, 45, 12 (2020)

7. M.M. Eamonn Clinical Gastroenterology and Hepatology, 17, 333 (2019)

8. N.S. Rodionova, E.S. Popov, V.Yu. Kustov, A.A. Rodionov, N.A. Rodionova International Journal of Civil Engineering and Technology, 10, 1718 (2019)

9. T.V. Alekseeva, L.O. Ryaskina, A.A. Rodionov, N.V. Safonova, N.A. Pastukhova News of higher educational institutions. Food technology, 4, 44 (2016)

10. N.S. Rodionova, E.S. Popov, N.A. Actual Biotechnology, 3, 313 (2019)

11. A.M. Osintsev Technique and technology of food production, 14, 25 (2013)

12. L.E. Glagoleva, M.I. Korystin, A.A. Rodionov, N.A. Pastukhova Bulletin of Voronezh State University of Engineering Technologies, 4, 160 (2016) 